\title{
PANDANGAN M. QURAISH SHIHAB TENTANG POSISI ALQURAN DALAM PENGEMBANGAN ILMU
}

\author{
Wedra Aprison \\ Institut Agama Islam Negeri (IAIN) Bukittinggi \\ Jl. Paninjauan Garegeh MKS Bukittinggi, Sumatera Barat \\ E-mail:wedraaprisoniain@gmail.com
}

\begin{abstract}
The View of M. Quraish Shihab on the Position of the Quran in Science Development. The Moslem scholars disagree over the relationship between the Quran and science. Al-Ghazâlî, for example, states that all branches of science, both the already and the unknown, derived from the Quran. While Al-Syâthîbi 's view is different from Al-Ghazâlî thus it needs to clearance the position of the Quran in the development of knowledge. The research question is how the position of the Quran in the development of science according to the view of M. Quraish Shihab? This study was conducted using a philosophical approach. The conclusion of this research is that the position of the Quran in the development of science more as an ethical basis rather than as a source of science or epistemological base. The Quran is a support for Moslem to seek, research, and develop science. It means that the Quran fills the axiology of scientific development.
\end{abstract}

Keywords: the Quran; epistemology; and science methodology.

\begin{abstract}
Abstrak: Pandangan M. Quraish Shihab tentang Posisi Alquran dalam Pengembangan Ilmu. Para ulama berselisih pendapat tentang hubungan Alquran dengan ilmu. Al-Ghazâlî misalnya, menyatakan bahwa seluruh cabang ilmu, baik yang telah maupun yang belum diketahui, bersumber dari Alquran. Sementara Al-Syâthîbi berbeda dengan Al-Ghazâlî di atas. Maka perlu didudukkan posisi Alquran dalam pengembangan ilmu. Pertanyaan penelitian ini adalah bagaimana posisi Alquran dalam pengembangan ilmu menurut pandangan M. Quraish Shihab? Penelitian dilakukan dengan menggunakan pendekatan filosofis. Setelah dilakukan analisis, maka simpulan penelitian ini adalah bahwa posisi Alquran dalam pengembangan ilmu lebih sebagai basis etis ketimbang sebagai sumber ilmu atau basis epistemologis. Alquran adalah sebagai pendorong bagi umat Islam untuk mencari, meneliti, dan mengembangan ilmu. Artinya Alquran mengisi ruang aksiologi pengembangan keilmuan.
\end{abstract}

Kata kunci: Alquran; epistemologi; dan metodologi ilmu.

\section{Pendahuluan}

Dalam Islam, Alquran mempunyai posisi yang sangat sentral dan penting. Manna' Al- Qaththan' ${ }^{1}$ menjelaskan bahwa Alquran memecahkan persoalan kemanusiaan di berbagai segi kehidupan, baik berkaitan dengan masalah kejiwaan, jasmani, sosial, ekonomi, maupun politik

1 Manna' Al- Qaththan, Mabâhits fî 'ulum al-Qur'an, terj. Aunur Rafiq El-Mazni, (Jakarta: Pustaka Alkautsar, 2012), h.15. Raghib As-Sirjani, mengatakan bahwa Alquran mengandung kaidah-kaidah umum dan berbagai macam hukum yang mengatur hubungan manusia dengan dirinya, hubungan dengan Tuhannya, hubungan dengan komunitas masyarakatnya, dan sesama saudaranya. Raghib As-Sirjani, Mazda Qaddamal Muslimûna lil 'Alam Ishamâtu al-Muslimîn fî al-Hadhârah alInsâniyah, terj.Sonif, (Jakarta: Pustaka Al-Kautsar, 2012), h. 40 dengan pemecahan yang penuh bijaksana. Husain Hariyanto ${ }^{2}$, menjelaskan bahwa sumber inspirasi yang menjadi penggerak dan elan vital luar biasa bagi para sarjana Muslim dalam mengembangkan berbagai ilmu yang mencerahkan peradaban dunia dapat dilacak pada sumber ajaran Islam itu sendiri, yaitu Alquran. Sedangkan Muhammad Iqbal menjelaskan bahwa nilai-nilai Alquran memiliki karakter yang dinamis, kongkrit, dan nyata, sehingga mendorong kaum Muslimin melakukan eksperimen dan berfikir induktif. ${ }^{3}$

\footnotetext{
2 Husain Hariyanto, Menggali Nalar Saintifik Peradaban Islam, (Bandung: Mizan, 2011), h. 38-39

3 Husain Hariyanto, Menggali Nalar Saintifik ..., h. 40. Hanya saja, situasi internal umat Islam yang amat memprihatinkan yakni krisis epistemologis dengan memudarnya kesadaran
} 
Meskipun Alquran menempati posisi yang penting dalam peradaban Islam, ${ }^{4}$ akan tetapi perlu mendudukkan kembali posisi Alquran, khususnya dalam pengembangan ilmu. Hal ini disebabkan tidak sedikit dari umat Islam hingga saat ini masih berdebat dalam memposisikan Alquran dan hadis dalam pengembangan ilmu. Antara lain dengan mengatakan, pertama, seluruh kandungan dalam keduanya adalah ilmiah dan tidak bertentangan dengan prinsip-prinsip ilmu dan teknologi; kedua, ilmu apapun yang dikembangkan umat manusia telah ada dalam dua sumber Islam tersebut. Masdar Hilmy 5 menjelaskan bahwa selama ini Alquran dan hadis diposisikan oleh umat Islam sebagai sumber ilmu dari pengembangan ilmu dan teknologi. Oleh sebab itu, keduanya dapat dijadikan rujukan langsung dalam upaya pengembangan ilmu apapun di dunia ini.

Selanjutnya, Ahmad Zainul $\mathrm{Hamdi}^{6}$ mengatakan, meletakkan Alquran sebagai sumber ilmu adalah merupakan sebuah jebakan, dan bisa jadi akan menjadi titik rawan ketertutupan semangat akademis. Karena garis pembatas pendefinisian antara ilmu Islami (berdasarkan Alquran dan hadis) dan ilmu sekuler-non Islami (yang dirumuskan tidak dengan merujuk pada kedua sumber tersebut), tanpa disadari, akan "menyortir" sebuah teori bukan berdasarkan isi dan metodenya, melainkan ada ayat-hadisnya atau tidak7.

untuk memahami ajaran-ajaran normatif agamanya secara kontekstual. Menghadapi perubahan-perubahan, umat Islam masih berpangku tangan dan menyandarkan diri pada beban sejarah masa lalu yang sudah lapuk. Inovasi berfikir sangat jarang dilakukan, dan kalaupun ada umat Islam selalu merujuk masa lalu, seolah-olah masa kini dan masa depan tidak menyediakan jawaban memuaskan bagi persoalan yang mereka hadapi. Umat Islam dengan mudah tergoda untuk mengurung diri dari perubahan dan sudah merasa cukup puas dengan berlindung di balik tempurung tradisi. Ziauddin Sardar, Islam, Postmodernism, and Other Futures, terj.R. Cecep Lukman Yasin dan Helmi Mustafa, (Jakarta: Serambi Ilmu Semesta, 2005), h. 8

4 Alquran dalam studi Islam memang menempati kedudukan yang sangat signifikan sebagaimana pentingnya kedudukan al-Qur'an sebagai teks fundamental dalam Islam. Jajang A. Rohmana, “ Rekonstruksi Ilmu-Ilmu Keislaman” dalam Kalam: Jurnal Studi Agama dan Pemikiran Islam, No. 1, 2014, h. 1

5 Masdar Hilmy, "Induktivisme Sebagai Basis Pengembangan Ilmu Pengetahuan Dalam Islam”, dalam Ulumuna Jurnal Studi Keislaman, No. 1 Juni 2013, h. 99

${ }^{6}$ Ahmad Zainul Hamdi, Menilai Ulang Gagasan Islamisasi Ilmu Sebagai Blu Print Pengembangan Keilmuan UIN, dalam Integrasi Ilmu dan Agama: Interpretasi dan Aksi,ed. Zainal Abidin Bagir, dkk (Bandung: Mizan, 2005),h. 197

${ }^{7}$ Lagi pula, sains Islam sampai saat ini masih terkungkung
Jika dilihat dari kalangan ulama, Qurasih Shihab ${ }^{8}$ menjelaskan bahwa para ulama berselisih pendapat tentang hal ini. Imam Al-Ghazâlî dalam kitabnya Jawâhir al-Qur'an menjelaskan bahwa seluruh cabang ilmu pengetahuan yang terdahulu dan yang kemudian, yang telah diketahui maupun yang belum, semua bersumber dari Alquran Nûr Karîm. Sementara itu, Imam Al-Syâthîbi dalam kitabnya Al-Muwâfaqât tidak sependapat dengan Al-Ghazâlî di atas. Al-Syâthîbi berpendapat bahwa para sahabat tentu lebih mengetahui Alquran dan apa-apa yang tercantum di dalamnya, tapi tidak seorangpun di antara mereka yang menyatakan bahwa Alquran mencakup seluruh cabang ilmu pengetahuan.

Tulisan ini akan menfokuskan pada pandangan M. Quraish Shihab yang punya otoritas secara akademik dalam menafsirkan dan menjelaskan Alquran, termasuk yang berkaitan dengan posisi Alquran dalam pengembangan ilmu. Di sisi lain, pengembangan ilmu merupakan suatu kemestian dilakukan oleh umat Islam di masa sekarang dan akan datang.

\section{Metodologi Pengembangan IImu}

Metodologi merupakan pengembangan ilmu sebagai landasan analisis atau landasan teori. Ahmad Tafsir ${ }^{9}$ menjelaskan bahwa orang yang mempelajari bahasa Arab mengalami sedikit kebingungan menghadapi kata ilmu. Dalam bahasa Arab kata ilmu berarti pengetahuan, sedangkan kata ilmu dalam bahasa Indonesia merupakan terjemahan dari kata science. IImu dalam arti science itu hanya sebagian saja dari makna kata al-'ilm dalam bahasa Arab. Disisi yang lain pengetahuan diartikan dengan semua yang diketahui. Sony Keraf ${ }^{10}$ menjelaskan bahwa

dalam lingkaran pseudoscience, atau masih pada taraf model justifikasi Bucaillian. Mohamad Muslih, "Sains Islam dalam Diskursus Filsafat IImu”, dalam Jurnal Kalam: Jurnal Studi Agama dan Pemikiran Islam, No.1 Juni, 2014, h. 1

${ }^{8}$ M. Quraish Shihab, Membumikan Alquran: Fungsi dan Peran Wahyu dalam Kehidupan Masyarakat (Bandung: Mizan, 1995), h. 41. Perdebatan para intelektual muslim dalam usaha membangun ilmu Islam sacera sengit dapat dibaca dalam karya Ziauddin Sardar, Reconstructing the Muslim Civilization, terj. AE. Priyono, (Surabaya: Risalah Gusti, 2000), h. 1-18

${ }_{9}^{9}$ Ahmad Tafsir, Filsafat Ilmu: Mengurai Ontologi, Epistemologi, dan Aksiologi Pengetahuan, (Bandung: Rosdakarya, 2007), h. 3

${ }^{10}$ A. Sonny Keraf, Ilmu Pengetahuan: Sebuah Tinjauan Filosofis, (Yogyakarta: Kanisius, 2001),h. 32 
pengetahuan adalah tahu bahwa seseorang mengetahui sesuatu. Alquran menjelaskan bahwa tatkala manusia masih dalam perut ibunya, ia tidak tahu apa-apa. Semasa bayipun mungkin masih belum punya pengetahuan. Baru setelah dewasa manusia sudah banyak pengetahuan. Selanjutnya Keraf menjelaskan bahwa untuk benar-benar terjadi suatu pengetahuan, maka diperlukan dua syarat, yaitu: (1) kesadaran bahwa di luar sana ada pohon; (2) kesadaran bahwa saya sedang sadar bahwa luar sana ada pohon. Hanya dengan kesadaran tingkat kedua inilah, seseorang benar-benar punya pengetahuan tentang sesuatu, tentang pohon di luar sana. Ini terutama untuk menghindari dan membedakan pengetahuan dari sekedar menebak atau mengira.

Dari segi motif, pengetahuan terbagi dua, yaitu: (1) pengetahuan yang diperoleh begitu saja, tanpa niat, tanpa motif, tanpa keingintahuan dan tanpa usaha; (2) pengetahuan yang didasari motif ingin tahu. Pengetahuan yang diperoleh karena diusahakan, hasilnya tahu sesuatu. Jadi dapat dikatakan bahwa pengetahuan itu ada yang diusahakan dan ada yang tidak diusahakan, dan keduanya disebut pengetahuan. Pengetahuan yang diusahakan atau karena motif rasa ingin tahu manusia, inilah yang disebut ilmu. Dalam bahasa Indonesia, sering disebut dengan pengetahuan sains atau ilmu pengetahuan, atau scientific knowledge.

Ilmu adalah pengetahuan yang rasional dan didukung oleh bukti empiris ${ }^{11}$. Namun, gejala yang paling menonjol dalam pengetahuan sains adanya bukti empiris. Endang Saifuddin Anshari' ${ }^{2}$ menjelaskan bahwa ilmu adalah pengetahuan yang memiliki sistem, dan metode tertentu yang dengan sangat sadar menuntut kebenaran. Pada umumnya, ilmu didefinisikan sebagai

\footnotetext{
${ }^{11}$ Ahmad Tafsir, Filsafat IImu..., h. 22

${ }^{12}$ Endang Saifuddin Anshari, Wawasan Islam: Pokok-pokok Pikiran Tentang Paradigma dan Sistem Islam, (Jakarta: Gema Insani, 2004), h. 108. Mulyadi Kartanegara mendefinisikan, sains merupakan hasil terbaik dari observasi indrawi manusia terhadap dunia fisik.Sedangkan filsafat beroperasi pada tingkat yang lebih tinggi daripada dunia fisik, yakni metafisika. Tentu saja para ilmuwan Muslim akan mengatakan bahwa sains berkutat pada dunia indrawi, sedangkan filsafat pada dunia akal. Jika objek-objek indrawi dapat ditangkap oleh indra, objek-objek ma'qulat hanya dapat ditangkap oleh akal pikiran. Mulyadi Kartanegara, Menyibak Tirai Kejahilan: Pengantar Epistemologi Islam, (Bandung: Mizan, 2003), h. 10
}

sejenis pengetahuan, tetapi bukan sembarang pengetahuan, melainkan pengetahuan yang diperoleh dengan cara-cara tertentu berdasarkan kesepakatan di antara para ilmuwan. Oleh karena itu, ilmu memiliki karakteristik yang berbeda dengan jenis pengetahuan yang lain yang dimiliki oleh manusia. Wilayah kajian ilmu adalah apa yang ada, sejauh yang dapat ditangkap oleh panca indra manusia, tanpa atau melalui peralatan teknologi canggih yang diciptakan oleh manusia. Wilayah kajian ilmu adalah dunia empirik, dunia fisik atau dunia materi. Apa yang tidak dapat ditangkap oleh panca indra, walau diyakini adanya oleh banyak manusia, seperti Tuhan, dewa, ruh manusia, dan jin, tidaklah masuk dalam kajian ilmu. Dunia modern telah membedakan ilmu dengan filsafat. Filsafat tidak lagi mencakup ilmu. Artinya ilmu telah dilepaskan dari kandungan filsafat. Kajian ilmu juga tidak diarahkan kepada persoalan etis dan aestetis ${ }^{13}$.

Dalam pengembangannya ${ }^{14}$, ilmu mempunyai metodologi tertentu. Ahmad Tafsir menjelaskan bahwa logico-hypothetico-verificatif merupakan langkah untuk memperoleh pengetahuan yang benar, yaitu: (1) mula-mula buktikan bahwa itu logis, (2) ajukan hipotesis (berdasarkan logika itu), (3) lakukan pembuktian hipotesis itu secara empiris. Jujun S. Suriasumantri'15 menjelaskan bahwa metode ilmiah merupakan ekspresi mengenai cara kerja pikiran. Dalam hal ini metode ilmiah adalah mencoba menggabungkan cara berfikir deduktif dan induktif dalam membangun tubuh pengetahuannya.

Jujun ${ }^{16}$ dengan mengutip John Dewey, mengatakan bahwa kegiatan ilmiah dimulai dari adanya masalah atau kesukaran yang dirasakan bila kita menemukan sesuatu dalam pengalaman kita yang menimbulkan pertanyaan. Pertanyaan itu

13 Abdul Aziz Dahlan, Pemikiran Falsafi dalam Islam, (Padang: IAIN-IB Press, 1999), h. 23

${ }^{14}$ Di tempat lain Ahmad Tafsir menjelaskan bahwa mengembangkan ilmu dapat dilakukan dengan cara mengembangkan teori-teori ilmu tersebut. Pertanyaan selanjutnya apa arti mengembangkan teori? Mengembangkan teori dapat berarti: (1) merevisi teori; (2) mengganti teori lama dengan teori baru; (3) membuat teori. Ahmad Tafsir, Epistemologi Untuk Ilmu Pendidikan Islam, (Bandung: Fakultas Tarbiyah IAIN Sunan Gunung Djati Bandung, 1995), h. 1

15 Jujun S. Suriasumantri, Filsafat Ilmu Sebuah Pengantar Populer, (Jakarta: Surya Mutia Grafika, 2005),h. 124

${ }^{16}$ Jujun S. Suriasumantri, Filsafat Ilmu...., h. 124. 
timbul disebabkan kontak manusia dengan dunia empiris. Dapat dikatakan karena ada masalah maka proses kegiatan berpikir dimulai, dan karena masalah ini berasal dari dunia empiris, maka berpikir tersebut diarahkan pada pengamatan obyek yang bersangkutan.

Karena masalah yang dihadapinya adalah nyata, maka ilmu mencari jawabanya pada dunia yang nyata pula. IImu dimulai dengan fakta dan berakhir dengan fakta. Antara keduanya dijembatani oleh teori. Jadi teori adalah penjelasan mengenai gejala yang terdapat dalam dunia fisik. Teori adalah merupakan suatu abstraksi intelektual di mana pendekatan secara rasional digabungkan dengan pengalaman empiris. Artinya, teori ilmu merupakan suatu penjelasan rasional yang berkesesuaian dengan obyek yang dijelaskannya. Suatu penjelasan, biar bagaimanapun meyakinkannya, tetap harus didukung oleh fakta empiris untuk dapat dinyatakan benar. Dengan demikian dapat dikatakan bahwa semua teori ilmiah harus memenuhi dua syarat utama, yaitu: (1) harus konsisten dengan teori-teori sebelumnya secara keseluruhan, (2) harus cocok dengan fakta-fakta empiris, sebab teori bagaimanapun konsistennya sekiranya tidak didukung oleh pengujian empiris tidak dapat diterima kebenarannya secara ilmiah. Disinilah pendekatan rasional digabungkan dengan pendekatan empiris atau penggabungan logika deduktif dan logika induktif. Langkah-langkah inilah yang disebut dengan metode ilmiah.

Manusia menghadapi masalah, dalam rangka menyelesaikan masalah tersebut dicarikan jawaban. Semua jawaban atau penjelasan rasional yang diajukan yang belum dibuktikan kebenarannya disebut dengan hipotesis. Hipotesis pada dasarnya disusun secara deduktif dengan mengambil premis-premis dari pengetahuan ilmiah yang sudah diketahui sebelumnya. Penyusunan seperti ini memungkinkan terjadinya konsistensi dalam mengembangkan ilmu secara keseluruhan dan menimbulkan pula efek kumulatif dalam kemajuan ilmu. Maka dengan demikian, kemajuan ilmu sebenarnya tidak dilakukan oleh sekelompok kecil jenius dengan buah pikirannya yang monumental, melainkan oleh manusiamanusia biasa yang selangkah demi selangkah menyusun tumpukan ilmu berdasarkan penemuan sebelumnya.

Langkah sesudah penyusunan hipotesis adalah pengujian hipotesis. Pengujian hipotesis merupakan pengumpulan fakta-fakta yang relevan dengan hipotesis yang diajukan. Fakta-fakta ini kadang-kadang bersifat sederhana dan kadang bersifat sangat rumit, sehingga memerlukan bantuan alat yang canggih. Hipotesis yang diterima kemudian dianggap menjadi bagian dari pengetahuan ilmiah, sebab telah memenuhi persyaratan keilmuan yakni mempunyai kerangka penjelasan yang konsisten dengan pengetahuan ilmiah sebelumnya serta telah teruji kebenarannya.

Secara sederhana metode pengembangan ilmu adalah logico-hepothetico-verificatif. Penjelasannya adalah: (1) perumusan masalah yang merupakan pertanyaan mengenai obyek empiris yang jelas batas-batasnya serta dapat diidentifikasi faktor-faktor yang terkait di dalamnya, (2) penyusunan kerangka berfikir dalam pengajuan hipotesis yang merupakan argumentasi yang menjelaskan hubungan yang memungkinkan terdapat antara berbagai faktor yang saling mengait dan membentuk konstelasi permasalahan, (3) perumusan hipotesis yang merupakan jawaban sementara atau dugaan terhadap pertanyaan yang diajukan yang materinya merupakan kesimpulan dari kerangka berpikir yang dikembangkan, (4) pengujian hipotesis yang merupakan pengumpulan fakta-fakta yang relevan dengan hipotesis yang diajukan untuk memperlihatkan apakah terdapat fakta-fakta yang mendukung hipotesis atau tidak, (5) penarikan kesimpulan yang merupakan penilaian apakah sebuah hipotesis yang diajukan itu ditolak atau diterima ${ }^{17}$. Jika diterima, maka terbentuklah teori. Teori itulah yang disebut ilmu.

\section{Posisi Alquran dalam Pengembangan Ilmu Pengetahuan}

Posisi Alquran dalam pengembangan ilmu pengetahuan menurut pandangan M. Quraish Shihab dapat dijajaki dan ditelusuri dalam karya-

${ }^{17}$ Jujun S. Suriasumantri, Filsafat Ilmu...., h. 128. Bandingkan dengan Keraf, langkah induksi gaya Bacon, pertama, adanya situasi masalah. Kedua, pengajuan hipotesis.Ketiga, penelitian lapangan.Keempat, pengujian hipotesis. A. Sony Keraf, Ilmu Pengetahuan..., h. 108 
karyanya, antara lain: (1)Wawasan Alquran: Tafsir Maudhu'i Atas Pelbagai Persoalan Umat, terbitan Mizan Bandung tahun 1996 cetakan ke-IV, (2) Membumikan Alquran: Fungsi Wahyu dalam Kehidupan Masyarakat, terbitan Mizan Bandung tahun 1995 cetakan ke-IX, (3) Menabur Pesan Ilahi: Alquran dan Dinamika Kehidupan Masyarakat, terbitan Lentera Hati Jakarta tahun 2006, (4) Tafsir al-Mishbah: Pesan Kesan dan Keserasian Alquran, terbitan Lentera Hati, Jakarta tahun 2005, jilid 1-15.

Kusmana sebagaimana dikutip oleh Abudin Nata $^{18}$ mengatakan bahwa dari keseluruhan karya M. Quraish Shihab dapat disimpulkan bahwa secara umum karakteristik pemikiran keislamannya bersifat rasional dan moderat. Sifat rasional pemikirannya tidak untuk memaksakan agama mengikuti kehendak realitas kontemporer, tetapi lebih mencoba memberikan penjelasan atau signifikansi agama klasik bagi masyarakat kontemporer atau mengekpresikan kemungkinan pemahaman dan penafsiran baru tetapi dengan tetap sangat menjaga kebaikan tradisi lama. Ade Budiman ${ }^{19}$ Mengatakan sumber penafsiran dalam tafsir Al-Mishbah dapat dikelompokkan pada sumber penafsiran bi al-ra'y. Kesimpulan ini berdasarkan pernyataan Quraish Shihab sendiri pada akhir sekapur sirih yang terdapat pada volume pertama tafsir Al-Mishbah.

Bardasarkan hasil kajian yang telah penulis lakukan terhadap karya-karya Quraish Shihab tersebut di atas dan dalam rangka menjawab pertanyaan pokok dalam penelitian ini, yakni bagaimana posisi Alquran dalam pengembangan ilmu menurut pandangan M. Quraish Shihab, maka dapat dipaparkan sebagai berikut:

\section{Tujuan Pokok Alquran}

Penjelasan dimulai dari mendudukkan fungsi Alquran dalam kehidupan, yakni sebagai petunjuk bagi kehidupan ini. Alquran memberikan petunjuk dalam persoalan-persoalan akidah, syariah, dan akhlak dengan jalan meletakkan dasar-dasar

\footnotetext{
${ }^{18}$ Abudin Nata, Tokoh-tokoh Pembaharuan Pendidikan Islam di Indonesia, (Jakarta: Raja Grafindo Persada, 2005), h. 365

${ }^{19}$ Ade Budiman, "Penafsiran Quraish Shihab Tentang AlFath Dalam Q.S. Al-Nashr”, Jurnal Mutawâtir: Jurnal Keilmuan Tafsir Hadis, No. 1 JuniTahun 2011, h. 34
}

prinsip mengenai persoalan-persoalan tersebut ${ }^{20}$. Quraish Shihab menguatkan penjelasannya dengan mengemukakan ayat (Q.S. An-Nahl [16] :44 dan Muhammad [47] :24).Penjelasan Alquran mengenai berbagai hal tidaklah tersusun sebagaimana halnya buku-buku ilmiah memberikan penjelasan dengan membaginya ke dalam bab-bab dan pasal-pasal tertentu. Persoalan akidah dijelaskan bergandengan dengan hukum, sejarah umat-umat terdahulu disatukan dengan nasehat, dorongan atau tanda-tanda kebesaran Allah yang ada di alam semesta. Terkadang ada suatu persoalan atau hukum yang sedang diterangkan tiba-tiba timbul persoalan lain yang pada pandangan pertama tidak ada hubungan antara satu dengan yang lainnya. Misalnya surat Al-Baqarah [2]: 216-221, yang mengatur hukum perang bergandengan dengan hukum minuman keras, perjudian, persoalan anak yatim, dan perkawinan dengan orang-orang musyrik. Hal ini dimaksudkan agar memberikan pemahaman bahwa ajaran-ajaran Alquran dan hukum-hukum yang terdapat di dalamnya merupakan satu kesatuan yang harus ditaati oleh penganutnya secara keseluruhan tanpa ada pemisahan antara satu dengan yang lainnya ${ }^{21}$.

Menjelaskan hubungan Alquran dengan ilmu adalah sangat diperlukan bagi perkembangan keduanya di masa datang. Hal ini karena keduanya juga sangat penting bagi kehidupan manusia. Dengan mengutip pendapat Whitehed, yang mengatakan bahwa bila kita menyadari betapa pentingnya agama bagi manusia dan betapa pentingnya ilmu, maka tidaklah berlebihan dikatakan bahwa sejarah kita yang akan datang bergantung pada putusan generasi sekarang mengenai hubungan antara keduanya. Pendapat Whitehed ini dapat dipahami, karena hubungan agama dan ilmu di Eropa tidaklah harmonis terutama di masa lalu pada abad ke-18. Hal yang sama juga sangat penting bagi umat Islam untuk

${ }^{20}$ Dalam Tafsir Al-Mishbah Quraish Shihab menjelaskan bahwa Alquran memiliki tiga aspek, yakni: akidah, syariah, dan akhlak. M. Quraish Shihab, Tafsir Al-Mishbah: Pesan, Kesan, dan Keserasian Alquran, , (Jakarta: Lentera Hati, 2005), Jilid ke-1, h. viii

${ }^{21}$ M. Quraish Shihab, Membumikan Alquran: Fungsi..., h. 34. Bahkan susunan ayat Alquran seperti ini mengandung unsur pendidikan yang amat menyentuh, lihat juga Tafsir AlMishbah, jilid ke-1, h. X 
merancang peradabannya di masa datang.

Meletakkan hubungan agama dengan ilmu pengetahuan secara proporsional akan memberikan pengaruh baik bagi masa depan Islam dan umat Islam ${ }^{22}$. Selanjutnya Karen Armstrong ${ }^{23}$ menjelaskan bahwa agama tidak boleh dibiarkan menghalangi kemajuan, tetapi harus membantu orang merangkul ketidakpastian masa depan. Tidak akan ada masalah bentrokan antara sains dan teologi, karena disiplin-disiplin ini memiliki lingkup kompetensi yang berbeda; sains tidak boleh terhalang oleh kekhawatiran beberapa orang bodoh dan orang-orang panik. Guiderdoni mengatakan bahwa sains menjawab pertanyaan bagaimana, sedangkan agama menjawab pertanyaan mengapa atau sains berurusan dengan fakta, sedangkan agama berurusan dengan nilai. Sains mempunyai wilayah yang berbeda dengan agama. Keduanya tidak boleh dicampur adukkan, tetapi juga tidak boleh dipisahkan sepenuhnya karena manusia harus menjadi manusia seutuhnya ${ }^{24}$.

\section{Kebenaran IImiah Alquran}

Fungsi Alquran dalam kehidupan adalah sebagai kitab petunjuk. Sesuai dengan penegasan Alquran sendiri yaitu petunjuk bagi manusia, keterangan mengenai petunjuk serta pemisah antara yang hak dan yang batil. (Q.S. Al-Baqarah [2]: 185). Jika demikian halnya, maka bagaimana hubungan Alquran dengan ilmu? Berkaitan dengan ini, memang terdapat perbedaan pendapat para ulama. Al-Ghazâlî misalnya, berpendapat bahwa seluruh cabang ilmu pengetahuan yang terdahulu dan yang kemudian, yang telah diketahui maupun yang belum, semua bersumber dari Alquran Alkarim. Sedangkan Imam Al-Syâthibi dalam kitabnya Al-Muwâfaqât berpendapat lain, para sahabat adalah orang yang lebih mengetahui Alquran dan apa-apa yang tercantum di dalamnya, tapi tidak seorangpun di antara mereka yang menyatakan bahwa Alquran mencakup seluruh cabang ilmu

${ }^{22}$ M. Qurais Shihab, Membumikan Alquran: Fungsi..., h. 34 .

${ }^{23}$ Karen Armstrong, The Case for God: What Religion Realy Means, terj,(Bandung: Mizan, 2009),h. 515

${ }^{24}$ Bruno Guiderdoni, Membaca Alam Membaca Ayat, terj. Anton Kurnia dan Andar Nubowo, (Bandung: Mizan, 2004), h. 45 pengetahuan. Perdebatan mengenai posisi Alquran dalam pengembangan ilmu nampaknya terjadi juga pada masa sakarang ini.

Setelah memaparkan perbedaan pendapat ulama, Quraish Shihab mengemukakan pendapatnya sendiri. la mengatakan bahwa membahas hubungan Alquran dan ilmu bukan dinilai dengan banyaknya cabang-cabang ilmu yang tersimpul di dalamnya, bukan pula dengan menujukkan kebenaran teori-teori ilmiah. Tetapi pembahasan hendaknya diletakkan pada proporsi yang lebih tepat sesuai dengan kemurnian dan kesucian Alquran dan sesuai pula dengan logika ilmu pengetahuan itu sendiri ${ }^{25}$. Ada istilah yang cukup populer di Indonesia yakni Iptek (IImu Pengetahuan dan Teknologi) dan Imtaq (Iman dan Taqwa). Keduanya pasti perbeda, karena kalau sama apa artinya jika menggunakan dua istilah itu serta memadukannya. Iptek sumbernya akal, dan Imtaq sumbernya kalbu, keduanya ada pada diri manusia dan dengan menyandingkan keduanya manusia bisa hidup bahagia.

Agamawan seringkali berusaha mengilmiahkan hal-hal yang bersifat suprarasional. Misalnya sebagian uraian tentang Isra' dan Mi'raj. Upaya semacam itu pada awalnya muncul ketika di Eropa terjadi konflik antara gereja yang menganut pandangan-pandangan yang bertentangan dengan penemuan ilmiah. Sebagian ulama yang khawatir ajaran Islam dituduh bertentangan dengan perkembangan ilmu, seringkali bersifat reaktif dengan "mengilmiahkan" tuntutan agama yang bersifat suprarasional. Hal itu terjadi karena kelemahan kita dalam menjelaskan hakikat ajaran Islam dan hanya terpaku pada salah satu dari sekian banyak potensi manusia.

Ketidakmampuan tersebut juga tidak terlepas dari kelemahan sebagian ulama dan pemikir pada zaman ini. Sebab, masa kecemerlangan Islam, ketika para ulama dan cendikiawannya mencapai keberhasilan dalam berbagai disiplin ilmu, termasuk yang kini kita namai ilmu-ilmu umum, mereka tetap mempertahankan keyakinan tentang hal-hal yang bersifat suprarasional, dan sama sekali tidak berusaha untuk menjadikannya rasional. Ketika itu mereka tidak "memaksakan"

${ }^{25}$ M. Quraish Shihab, Membumikan Alquran: Fungsi..., h. 41 
pembuktian kebenaran semua ajaran agama dengan cara menyesuaikannya dengan perkembangan ilmu².

Dalam pandangannya, Quraish Shihab sadar betul bahwa betapa problematiknya mengatakan Alquran sebagai sumber ilmu. Apa makna Alquran sebagai sumber ilmu? Kalau dikatakan semacam buku ilmu, pandangan ini tidak hanya naif, tetapi juga berbahaya. Cara berfikir seperti inilah yang disebut dengan Buchailisme yang sangat berbahaya. Kalau dikatakan Alquran sebagai sumber inspirasi, pertanyaan berikutnya adalah apakah seorang ilmuwan yang menggagas teorinya dari inspirasi tiba-tiba ketika dia merenung fenomena di sekitarnya, tidak atau kurang Islami teorinya dibandingkan dengan seorang ilmuwan yang mendapat inspirasi langsung dari Alquran? Kalau ya, pertanyaan berikutnya adalah dengan ukuran apa sebuah teori dikatakan Islami dan tidak Islami? Apakah sebuah teori dikatakan sebagai ilmiah didasarkan atas sumber inspirasinya atau kejujuran ilmiah ilmuwannya, sekalipun tidak terinspirasi dari Alquran. Sebuah ayat tidak bisa memberi priveles apa pun terhadap teori seseorang atas teori lain yang tidak ada ayatnya. Bahkan dua orang ilmuwan yang mendapatkan inspirasi dari Alquran, bisa jadi akan mengkonstruksi teori yang berbeda. Hal ini karena inspirasi Alquran lahir bukan dari sesuatu yang diberikan, melainkan disebabkan oleh cara seseorang memandang dan membaca Alquran. Lalu teori manakah yang yang lebih Islami? Kalau teori keduanya bersifat Islami, lalu apa bedanya dengan kegiatan ilmiah biasa yang di antara para ilmuwan bisa saling berbeda pendapat. Ada banyak problem epistemologis yang terkait dengan dua hal tersebut.Hal seperti ini harus dihindari, dan ini disadari betul oleh Quraish Shihab.

Argumen selanjutnya yang cukup tajam dikemukakan Qurais Shihab bahwa pengetahuan manusia disusun berdasarkan pengalaman dan penalaran. Kalau ada orang yang menggagas sebuah teori dalam disiplin ilmu apa saja berdasarkan inspirasi Alquran atau diturunkan dari premis-premis Alquran, maka teori tersebut

${ }^{26}$ M. Quraish Shihab, Menabur Pesan Ilahi: Alquran dan Dinamika Kehidupan Masyarakat, (Jakarta: Lentera Hati, 2006), h. 119 hanyalah menjadi salah satu teori dengan derajat yang sama persis dengan teori-teori lainnya. Ketika ada satu teori memberi lisensi kebenaran tunggal pada dirinya hanya karena ia terinspirasi atau yang langsung diturunkan dari premispremis Alquran, maka ini tidak sah. Konsekwensi selanjutnya tidak sah untuk menciptakan definisi oposisional antara ilmu Islami dan non-Islami atas dasar peletakan Alquran sebagai sumber pengetahuan atau sumber inspirasi.

Sebuah teori yang digagas oleh seorang Muslim tidak memiliki status unggul dibandingkan teori yang digagas oleh non-Muslim sebelum diuji secara fair. Tidak ada teori yang diunggulkan hanya karena memiliki rujukan ayat atau hadis atas sebuah teori yang tidak ada ayat atau hadisnya sebelum teori tersebut dinilai secara sungguh-sungguh. Seluruh teori darimana saja dan oleh siapa saja ia dilahirkan, harus diperlakukan secara sama untuk diuji dan dinilai, ditolak maupun diterima. Ini berlaku untuk seluruh ilmu, termasuk ilmu-ilmu yang selama ini termasuk kategori Islamic studies ${ }^{27}$.

Dalam analisa penulis, pendapat Quraish Shihab seperti ini melambangkan bahwa ia adalah orang yang sangat mengerti Alquran dan sekaligus ia sangat menguasi hakikat ilmu. Poin ini adalah paling krusial dalam penjelasan Quraish Shihab tentang hubungan Alquran dengan ilmu, dan merupakan inti dari pola hubungan itu. Quraish Shihab telah meletakkan posisi keduanya pada tempatnya yang tepat. Hanya saja seperti yang dikatakan oleh M. Amin Abdullah ${ }^{28}$, bahwa para mahasiswa dan juga dosen sering kali masih sulit untuk membedakan secara tegas-proporsional di mana wilayah keilmuan dan di mana wilayah keagamaan.

Membahas hubungan Alquran dengan ilmu bukan dengan melihat adakah teori relativitas, ilmu komputer, teori evolusi dalam Alquran, dan sebagainya.Tetapi yang lebih utama adalah melihat adakah jiwa ayat-ayatnya menghalangi

${ }^{27}$ Ahmad Zainul Hamdi, Menilai Ulang Gagasan Islamisasi IImu Sebagai Blu Print Pengembangan Keilmuan UIN, dalam Integrasi llmu dan Agama: Interpretasi dan Aksi,ed. Zainal Abidin Bagir, dkk, (Bandung Mizan, 2005), h. 200

${ }^{28} \mathrm{M}$. Amin Abdullah, Falsafah Kalam di Era Postmodernisme, (Yogyakarta: Pustaka pelajar, 1995), h. 17 
kemajuan ilmu atau sebaliknya, serta adakah satu ayat Alquran yang bertentangan dengan hasil penemuan ilmiah yang telah mapan? Dengan kata lain, meletakkannya pada sisi psikologi sosial (social psychology), dan bukan pada sejarah perkembangan ilmu pengetahuan (history of scientific progress). Anggaplah setiap ayat dalam Alquran mengandung suatu teori ilmiah, kemudian apa hasilnya? Apakah keuntungan yang diperoleh dengan mengetahui teori-teori tersebut bila masyarakat tidak diberi hidayah atau petunjuk guna kemajuan ilmu pengetahuan atau menyingkirkan hal-hal yang dapat menghambatnya?

Quraish Shihab menguatkan argumennya dengan mengutip pendapat Malik bin Nabi yang mengatakan bahwa ilmu adalah sekumpulan masalah serta sekumpulan metode yang dipergunakan menuju tercapainya masalah tersebut. Kemajuan ilmu bukan hanya terbatas dalam bidang-bidang tersebut, tetapi bergantung pula pada sekumpulan syarat-syarat psikologis dan sosial yang mempunyai pengaruh negatif dan positif sehingga dapat menghambat kemajuan ilmu atau mendorongnya lebih jauh. Ini menunjukkan bahwa kemajuan ilmu tidak hanya dinilai dengan apa yang dipersembahkannya kepada masyarakat, tetapi juga diukur dengan adanya suatu iklim yang dapat mendorong kemajuan ilmu pengetahuan.

Sejarah Eropa telah menunjukkan kepada kita bahwa Galileo ketika mengungkapkan penemuannya bahwa bumi ini beredar tidak mendapat sanggahan dari komunitas ilmiah. Tapi ia mendapat sanggahan atau penentangan atas dasar kepercayaan dogma, sehingga akhirnya ia menjadi korban dari belum terwujudnya syaratsyarat sosial dan psikologis yang disebutkan di atas. Artinya betapa belum terciptanya kondisi psikologis di tengah masyarakat Eropa pada saat itu. Sebagaimana yang dikatakan oleh Karen Armstrong ${ }^{29}$ apa yang tampaknya tidak disadari oleh Galileo adalah bahwa iklim politik telah berubah. Vatikan tidak lagi menganggap teologi sebagai ilmu pengetahuan spekulatif, tetapi secara sistematis menyusutkan ajaran Aristoteles dan Aquinas ke dalam serangkaian proposisi kaku yang

${ }^{29}$ Karen Armstrong, The Case for God: What Religion Realy Means, terj. Yuliani Liputo (Bandung: Mizan, 2009), h. 309 dirumuskan sedemikian rupa untuk mengakhiri semua diskusi dan memaksimalkan kepastian.

Pada 1605 Kardinal Jesuit Robert Bellarmine, yang melambangkan sikap baru ini telah menjadi teolog kepausan. Bagi Bellarmine, tugas teologi hanyalah untuk menata doktrin-doktrin ke dalam sebuah sistem rapi yang dapat dikerahkan secara efektif untuk melawan musuh-musuh gereja. Eksekusi Bruno telah teramat menjelaskan bahwa pejabat-pejabat kepausan siap untuk menegakkan doktrin ortodoksi baru menggunakan metode pemaksaan yang sama seperti semua monarki modern awal.

Faktor penting yang dapat menghalangi perkembangan ilmu pengetahuan terdapat di dalam diri manusia itu sendiri30. Dengan mengemukakan pendapat psikolog, bahwa perkembangan kejiwaan dan pikiran manusia dalam menilai suatu ide umumnya melalui tiga fase. Pertama, menilai baik dan buruknya suatu ide dengan ukuran yang mempunyai hubungan dengan alam kebendaan atau berdasarkan panca indra yang timbul dari kebutuhankebutuhan primer. Kedua, menilai ide tersebut atas keteladanan yang diberikan oleh seseorang. Artinya menilai ide dengan melihat siapa yang menyampaikan atau tidak terlepas dari individu sesorang. Ketiga, suatu penilaian tentang ide didasarkan atas nilai-nilai yang terdapat dalam unsur-unsur ide tersebut, tanpa terpengaruh atas faktor internal atau eksternal yang menguatkan dan melemahkannya. Sejarah Islam menujukkan bahwa pada masa-masa pertama dalam pembinaan masyarakat Islam, pandangan atau penilaian segolongan orang Islam terhadap nilai atau ide yang dibawa oleh Alquran, adalah bahwa ide tersebut mempunyai hubungan yang sangat erat

30 Di tempat lain Quraish Shihab menjelaskan bahwa hambatan yang paling besar guna meraih dan mengembangkan ilmu terdapat pada diri manusia. Keengganannya bertanya, baik karena malu maupun angkuh, adalah hambatan, karena itu Alquran memerintahkan untuk bertanya: tanyalah kepada orang-orang berpengetahuan jika kamu tidak tahu (Q.S. anNahl [16]: 43). Sambil menekankan bahwa di atas setiap yang berpengetahuan ada yang lebih mengetahui (Q.S. Yûsuf [12]: 76). Kedua penegasan atas menuntun yang tidak tahu agar jangan malu bertanya dan tidak menuntun yang mejawab, agar setiap orang jangan angkuh dengan pengetahuannya serta jangan malu berkata aku tidak tahu. M. Quraish Shihab. Menabur Pesan Ilahi: Al-Quran dan Dinamika Kehidupan Masyarakat, (Jakarta: Lentera, 2006),h. 145 
dengan pribadi Rasulullah Saw. Dalam perang Uhud misalnya, sekelompok kaum Muslimin cepatcepat meninggalkan medan pertempuran ketika mendengar berita wafatnya Rasulullah Saw, yang diisukan oleh kaum musyrik. Sikap keliru ini lahir dari akibat pandangan mereka menilai ide baru sampai pada fase kedua, yakni terfokus pada siapa atau individu atau kultus individu, belum sampai pada tingkat kedewasaan seperti tahap ketiga ${ }^{31}$.

Alquran mendorong untuk bersikap lebih dewasa, yakni melihat ide lebih kepada substansi ide dari pada sekedar melihat darimana datangnya ide tersebut. Ini dapat dilihat dalam surat Âli'Imrân [3]: 66 dan 144, dan surat Az-Zumar [39]: 9. Ayat-ayat ini mengkritik terhadap mereka yang berbicara atau membantah suatu persoalan tanpa adanya data objektif lagi ilmiah yang berkaitan dengan masalah yang dibicarakan ${ }^{32}$. Ayat-ayat seperti inilah yang kemudian membentuk iklim baru yang dapat medorong kemajuan ilmu. Iklim seperti inilah yang telah melahirkan tokoh-tokoh besar dalam sejarah Islam, seperti: Ibnu Sina, Al-Farabi, Al-Ghazali, Ibnu Khaldun, Jâbir Ibnu Hayyan, dan lain sebagainya. Kondisi seperti inilah yang membantu Muhammad bin Ahmad menemukan angka nol pada tahun 976, yang akhirnya mendorong Muhammad bin Musa AlKhawârizmiy menemukan perhitungan Aljabar. Tanpa penemuan-penemuan tersebut, ilmu pasti akan tetap merangkak dan meraba-raba dalam alam kegelapan.

Selanjutnya Quraish Shihab menjelaskan relativitas kebenaran ilmu. Kalau demikian halnya sifat dan hakikat ilmu pengetahuan, dengan nada bertanya, dapatkah kita menguatkan atau membatalkan teori atau temuan ilmiah dengan ayat-ayat Tuhan yang bersifat absolut, abadi, dan pasti benar?33Relakah kita mengubah arti

\footnotetext{
${ }^{31}$ M. Quraish Shihab, Membumikan Alquran: Fungsi..., h. 43

${ }^{32}$ M. Quraish Shihab, Tafsir Al-Mishbah: Pesan, Kesan, dan Keserasian Alquran, (Jakarta: Lentera Hati, 2005), Jilid ke-2, h. 117

33 John F. Haugth sebagaimana yang dikutip oleh Wedra Aprison, "sains tidak berusaha membuktikan keberadaan Tuhan. Dia tidak menopang ajaran-ajaran keagamaan dengan mengacu kepada konsep-konsep ilmiah.Sudah tidak masanya gagasan ilmiah dapat digunakan untuk memperkuat argumen eksistensi Tuhan. Tapi, toh masih diyakini juga bahwa, tanpa melakukan campur tangan ke dalam metode-metode yang khas bagi seorang ilmuwan, keyakinan keagamaan dapat tumbuh subur di samping sains hal itu terjadi dengan cara sedemikian rupa sehingga keduanya sama-sama menghasilkan
}

ayat Alquran sesuai dengan perubahan atau teori ilmiah yang tidak atau belum mapan? Tidakkah ini memberikan kesempatan kepada musuh-musuh Alquran atau bahkan kepada kaum Muslimin sendiri untuk meragukan kebenaran Alquran? Demikian juga mengingkari suatu teori ilmiah berdasarkan ayat-ayat Alquran sangat berbahaya, karena akses yang ditimbulkan tidak kurang bahayanya dengan apa yang muncul di Eropa ketika gereja mengingkari teori ilmiah Galileo.

Bila seseorang membenarkan satu teori ilmiah berdasarkan Alquran berarti pula dia mewajibkan setiap Muslim untuk mempercayai teori tersebut. Sebagian ilmuwan Muslim mengingkari teori evolusi Darwin dengan beberapa ayat Alquran atau membenarkan dengan beberapa ayat Alquran juga. Dengan mengemukakan pendapat Rasyid Ridha yang mengatakan bahwa teori Darwin tidak membatalkan, atau bila teori tersebut benar dan merupakan hal yang nyata, tentang satu dasar dari dasar-dasar Islam; tidak bertentangan dengan satu ayat dari ayat-ayat Alquran. Sebab teori tersebut adalah ilmiah, dan bukan persoalan agama sedikitpun. Franz Magnis Suseno ${ }^{34}$ dalam epilog buku the origin of species Darwin, mengatakan bahwa buku Darwin tentang asal usul spesies memang mengubah cara manusia memahami diri dan dunianya secara mendalam. Kiranya tidak ada jalan kembali ke alam praevolusi, kecuali jalan denial fundamentalistik yang berarti orang menutup diri terhadap apa yang nyata. Namun menerima evolusi tidak harus membuat orang menjadi materialistik dan tidak perlu memperlemah imannya. Comte memang benar bahwa manusia harus meninggalkan mitos dan memakai ilmu, akan tetapi kepercayaan agama bukanlah mitos dan karena itu tidak tersingkir oleh ilmu. Apabila kita membaca kembali kitabkita suci dalam cakrawala pengertian evolusi, kebijaksanaan penciptaan Ilahi malah lebih bersinar. Sebagaimana dijelaskan oleh Teilhard

satu makna, suatu makna yang lebih cerah ketimbang makna yang dapat diberikan oleh salah satu dari keduanya". Wedra Aprison, "Mendamaikan Sains dan Agama: Mempertimbangkan Teori Harun Nasution”, dalam Jurnal Pendidikan Islam, No. 2 Desember 2015, h. 247

${ }^{34}$ Franz Magnis Suseno dalam epilog Charles Drawin, The Origin of Species: by Means of Natural Selection or the Preservatiom of Favoured Races in the Struggle for life, terj. TIM UNAS, (Jakarta: Yayasan Obor Indonesia, 2003), h. 469 
de Chardion, alam raya menjadi proses antara alpha dan omega, antara Allah pencipta yang merupakan asal usul semula dari segala yang ada, dan tujuan segala tujuan, Allah yang sama kepada-Nya segala apa yang ada merentangkan diri, berkembang dan menuju iman, melainkan justru memberikan dimensi baru kepadanya.

Kita tidak dapat membenarkan dan begitu juga menyalahkan teori ilmiah dengan ayat-ayat Alquran; sebab hal itu, membuka jalan bagi penentang Islam untuk menyalahkan Alquran. Sikap yang paling bijaksana dalam menghindarkan cemooh adalah menghindarkan sebab-sebab cemoohan itu, Q.S. Al-An'âm [6]: 108. Tidak bisa dipungkiri, memang ayat-ayat Alquran menyinggung secara sepintas lalu kebenaran-kebenaran ilmiah yang belum ditemukan atau diketahui manusia di masa turunnya Alquran. Setiap orang bebas dan berhak menyatakan apa yang dianggapnya benar, tetapi ia tidak berhak untuk menguatkan pendapatnya dengan ayatayat tersebut dengan memahaminya lebih dari apa yang tersimpul di dalamnya. Karena dengan demikian ia menjadikan pendapatnya sebagai satu akidah dari aqidah Qur'âniyah, dan juga tidak berhak menyalahkan satu teori atas nama Alquran.

\section{Hikmah Ayat IImiah Alquran}

Quraish Shihab memulai penjelasannya dengan tujuan pemaparan kebenaran ilmiah dalam Alquran adalah untuk menunjukkan kebesaran Tuhan dan Keesaan-Nya, serta medorong manusia seluruhnya untuk mengadakan observasi dan penelitian demi lebih menguatkan iman dan kepercayaan kepada-Nya. Dengan mengutip Muhammad Syaltut yang mengatakan sesungguhnya Tuhan tidak menurunkan Alquran untuk menjadi satu kitab yang menerangkan kepada manusia mengenai teoriteori ilmiah, problem-problem seni serta aneka warna pengetahuan. Quraish mengemukakan kasus pada suatu hari datang seseorang kepada Rasul dan bertanya: mengapa bulan kelihatannya kecil bagaikan benang, kemudian membesar sampai sempurna purnama? Hal ini dijawab dengan surat alBaqarah [2]: 189, mereka bertanya kepadamu perihal bulan. Katakanlah bulan itu untuk menentukan waktu bagi manusia dan mengerjakan haji. Pada kali yang lain ada juga yang bertanya: mengenai ruh, lalu Alquran menjawab: mereka bertanya kepadamu tentang ruh. Katakan: Ruh adalah urusan
Tuhanmu, kamu sekalian hanya diberi sedikit ilmu pengetahuan. Jawaban Alquran terhadap dua kasus di atas jelas bukan jawaban ilmiah, sebab ia bukan buku atau kitab ilmiah. Jawabannya sesuai dengan tujuan pokoknya yaitu memberikan petunjuk kepada manusia demi kebahagiaan hidupnya di dunia dan di akhirat. Di samping itu, jawaban ilmiah berdasarkan astronomi itu belum dapat terjangkau oleh penanya pada waktu itu. Dengan demikian ayat ini mengajarkan agar tidak menjawab persoalan yang tidak termasuk otoritas anda, tidak juga memberikan jawaban yang diduga keras tidak dimengerti oleh penanya, sebagaimana ia mengajarkan agar mengarahkan penanya kepada pertayaan dan jawaban yang bermanfaat baginya ${ }^{35}$. Dengan demikian maksud dari ayat mâ farrathnâ fî al-kitâb min syay' (Q.S. al-An'âm [6]: 38), dan wa nazzalnâ 'alayka al-kitâb thibyânan likullî syay' (Q.S. an-Nahl [16] :89), adalah bahwa Alquran tidak meninggalkan sedikitpun dan atau lengah dalam memberikan keterangan mengenai segala sesuatu, min syay' dan likullî syay'36, yang berhubungan dengan tujuan-tujuan pokok Alquran, yaitu masalah-masalah akidah, syariah, dan akhlak, bukan sebagai apa yang dimengerti oleh sebagian ulama bahwa ia mencakup segala macam ilmu pengetahuan ${ }^{37}$.

${ }_{35}$ M. Quraish Shihab, Tafsir Al-Mishbah: Pesan..., Jilid ke1, h. 418, bandingkan denganM. Quraish Shihab, Membumikan Alquran: Fungsi...,h. 51-52

${ }^{36}$ Imam al-Ghazali memperluas cakupan makna ayat ini (Q.S. al- An'âm [6]: 38 dan Q.S. an-Nahl [16]: 89), semua jenis pengetahuan tidak keluar dari kandungan Alquran, karena semuanya bersumber dari samudra ilmu Allah yang tidak terbatas, pikirkanlah tentang Alquran, pelajarilah keajaiban-keajaibannya, akhirnya anda akan bertemu dengan keseruhan ilmu generasi terdahulu dan generasi kemudian. Imam al-Chazali mendasarkan pendapatnya ini pada hakikat yang tidak diingkari oleh siapapun yang mempercayai Allah, yaitu bahwa Allah mengetahui. Karena Alquran bersumber dari Allah, maka tentulah Alquran mencakup ilmu Allah. Logika seperti ini tidak sepenuhnya di dukung oleh para ulama, karena walaupun Alquran adalah kalam Allah, tetapi kalam tidak otomatis telah mencakup segala yang diketahui oleh pembicara, lebih-lebih jika disadari bahwa kalam Allah itu dasarnya hanya ditujukan kepada manusia, yang hidup sejak masa nabi Muhammad saw, ditambah lagi dengan kenyataan tidak semua ilmu ada dalam Alquran. Jadi kata segala sesuatu bila akan dikaitkan dengan Alquran haruslah dikaitkan dengan fungsi dan tujuan kehadiran kitab suci itu. Sebagai contoh, jika anda menugasi seseorang membeli 5 jenis barang, dan kelimannya telah dibelinya tanpa membawa barang-barang lain yang ditawarkan di pasar, maka tidaklah wajar jika anda berkata si A alpa atau melupakan sesuatu. M. Quraish Shihab, Tafsir Almishbah: Pesan, Kesan, dan Keserasian Alquran, Jilid ke-7, (Jakarta: Lentera Hati, 2005),h. 321

37 Baca lebih lengkap dalam M. Quraish Shihab, Tafsir Almishbah: Pesan, kesan, dan Keserasian Alquran, Jilid ke-3 dan 
Dengan demikian Alquran lebih tepat diletakkan sebagai basis etis kehidupan manusia. Fazlur Rahman sebagaimana yang dikutip oleh Abdul Mustaqim ${ }^{38}$, mengatakan bahwa Alquran dipandang oleh umat Islam sebagai sumber ajaran moral dan sekaligus petunjuk bagi umat manusia. Alquran tidak terikat dengan program-program riset ilmiah tentang penemuan atom, tetapi Alquran menyediakan basis etis dalam pengembangan ilmu. Jadi Alquran menjadi basis etis yang mengisi ruang aksiologi pengembangan keilmuan. Di sini nilainilai kemanusiaan: toleransi, kebenaran, kejujuran, harus dijunjung tinggi sebagai fondasi etis bagi seluruh aktivitas keilmuaan. Kalau situasi akademis yang hendak dikembangkan harus berwajah Islami, itu lebih pada sisi etis dari pada kesempitan dan kenaifan ilmiah.

Perlakuan kitab suci sebagai sumber kebenaran ilmu bisa mengganggu dan mengintervensi proses scientific inquiry yang dilakukan oleh ilmu. Mestinya kitab suci cukup diperlakukan sebagai sumber inspirasi, bukan sebagai sumber kebenaran ilmu yang bersifat verbatim. Semangat menjunjung tinggi pencarian obyektifitas ilmiah bisa terganggu karena eksistensi teks suci akan membayangi setiap jengkal proses inquiry dimaksud. Hal ini akan berakibat pada pemutlakan proses-proses ilmiah yang yang diangkat oleh ilmuwan dari hamparan data yang berserak. Sekali teks suci diangkat sebagai sumber ilmu-dari segala sumber kebenaran ilmiah, maka ia akan membayangi kemanapun pengembangan sains akan diarahkan. Takdis alafkâr al-'ilmi bisa saja terjadi akibat kemenyatuan antara sains dan kitab suci. Yang lebih fatal lagi, kitab suci tidak akan mampu melakukan pembelaan diri ketika teori-teori ilmiah yang dihasilkan oleh para ilmuwan terbukti tidak valid dan tidak berlaku kembali akibat terdapat teori pengganti yang jauh lebih valid. Dalam tradisi ilmiah sebuah teori dapat dianggap kadaluarsa (out of date) karena ada teori pengganti yang lebih valid, tidak demikian halnya dengan kitab suci. Dengan demikian, kebenaran teks suci haruslah ditempatkan secara proporsional bukan dalam perspektif ilmiah teoritik, melainkan sebagai inspirasi bagi umat Muslim dalam pencarian ilmiah yang tiada henti39.

\footnotetext{
4, (Jakarta: Lentera Hati, 2005), h. 86

${ }^{38}$ Abdul Mustaqim, Epistemologi Tafsir....,h. 2

${ }^{39}$ Masdar Hilmy, "Induktivisme Sebagai Basis Pengembangan Ilmu..., h. 102
}

Persoalan sebagian ilmuwan Muslim membenarkan dan menyalahkan teori Barat, maka Quraish Shihab memberikan penjelasan. Pertama, hal ini akibat dari rasa rendah diri umat Islam melihat kemajuan Barat. Kedua, akibat pertentangan yang hebat antara gereja dan ilmuwan sejak abad ke 18 di Eropa $^{40}$. Lalu kalau begitu, bagaimana kita memahami Alquran di abad modern ini? Umat Islam atau setiap orang diajak berdialog dengan Alquran sesuai dengan akal pikiran mereka. Dengan demikian memahami Alquran disesuaikan dengan tingkal akal pikiran masing-masing. Hal ini bukan berarti menafsirkan Alquran sesuai dengan teoriteori ilmiah atau penemuan-penemuan baru.Kita dapat menggunakan pendapat para cendikiawan dan ulama, hasil percobaan dan pengalaman para ilmuwan, mengasah otak dalam membantu mengadakan ta'amûl dan tadabbûr dalam membantu memahami ayat-ayat Alquran tanpa mempercayai setiap hipotesis atau pantangan ${ }^{41}$. Artinya menggunakan penemuan-penemuan baru adalah baik, selama paham tersebut tidak dipercayai sebagai ‘aqîdah Qur'âniyyah.

\section{Penutup}

Dari paparan di atas, maka dapat disimpulkan bahwa posisi Alquran dalam pengembangan ilmu lebih sebagai basis etis ketimbang sebagai sumber ilmu atau basis epistemologis. Alquran adalah sebagai pendorong bagi umat Islam untuk mencari, meneliti, dan mengembangan ilmu. Artinya Alquran mengisi ruang aksiologi pengembangan keilmuan. Mendudukkan posisi Alquran dalam pengembangan ilmu bukan dinilai banyaknya cabang-cabang ilmu yang tersimpul di dalamnya dan bukan pula menunjukkan kebenaran teori-teori ilmiah. Tetapi pembahasan hendaknya diletakkan pada proporsi yang lebih tepat sesuai dengan kemurnian dan kesucian Alquran dan sesuai pula dengan logika ilmu itu sendiri.

${ }^{40}$ Pendapat serupa juga dikemukan oleh Mehdi Golshani, sebagai berikut: hubungan sain dan agama dalam Islam telah menjadi salah satu topik yang panas dalam seratus lima puluh tahun terakhir. Sebuah fakta yang penting adalah bahwa kemajuan sains dan teknologi di Barat telah menimbulkan dampak yang besar pada masyarakat-masyarakat Muslim. Dunia Islam telah mencoba menyerap sebagian dari implikasiimplikasi metafisika dan sosial dari sains kontemporer.Mehdi Golshani, Melacak Jejak Tuhan Dalam Sains: Tafsir Islami atas Sains, (Bandung: Mizan, 2004), h. ix

${ }^{41}$ M. Quraish Shihab, Membumikan Alquran..., h. 57 


\section{Pustaka Acuan}

Abdullah, M. Amin, Falsafah Kalam di Era Postmodernisme, Yogyakarta: Pustaka Pelajar, 1995.

Anshari, Endang Saifuddin, Wawasan Islam: Pokokpokok Pikiran Tentang Paradigma dan Sistem Islam, Jakarta: Gema Insani, 2004.

Aprison, Wedra, "Mendamaikan Sains dan Agama: Mempertimbangkan Teori Harun Nasution”, dalam Jurnal Pendidikan Islam, UIN Yogyakarta: Volume IV, Nomor 2, Desember 2015.

Armstrong, Karen, The Case for God: What Religion Realy Means, terj. Yuliani Liputo. Bandung: Mizan, 2009.

As-Sirjani, Raghib, Mazda Qaddamal Muslimuna lil 'Alam Ishamaatu Al-Muslimîn fî al-Hadharah al-Insâniyah, terj. Sonif, Jakarta: Pustaka AlKautsar, 2012.

Bucaille, Maurice, La Bible Le Coran Etla Science,Terj. M. Rasyidi, Jakarta: Bulan Bintang, 1992.

Budiman, Ade, "Penafsiran Quraish Shihab Tentang Al-Fath Dalam Q.S. Al-Nashr. Jurnal Mutawâtir” dalam Jurnal Keilmuan Tafsir Hadis, Volume 1, Nomor 1, Juni 2011

Dahlan, Abdul Aziz, Pemikiran Falsafi dalam Islam, Padang: IAIN-IB Press, 1999.

Golshani, Mehdi, Melacak Jejak Tuhan Dalam Sains: Tafsir Islami atas Sains, Bandung: Mizan, 2004.

Guiderdoni, Bruno, Membaca Alam Membaca Ayat, terj. Anton Kurnia dan Andar Nubowo, Bandung: Mizan, 2004

Hamdi, Ahmad Zainul, Menilai Ulang Gagasan Islamisasi Ilmu Sebagai Blu Print Pengembangan Keilmuan UIN, dalam Integrasi IImu dan Agama: Interpretasi dan Aksi. Ed. Zainal Abidin Bagir, dkk, Bandung Mizan, 2005.

Hariyanto, Husain, Menggali Nalar Saintifik Peradaban Islam, Bandung: Mizan, 2011.

Hilmy, Masdar, "Induktivisme Sebagai Basis Pengembangan IImu Pengetahuan Dalam Islam", dalam Ulumuna Jurnal Studi Keislaman. Volume 17 Nomor 1, Juni 2013.

Kartanegara, Mulyadi, Menyibak Tirai Kejahilan: Pengantar Epistemologi Islam, Bandung: Mizan, 2003.

Keraf, A. Sonny, Ilmu Pengetahuan: Sebuah Tinjauan Filosofis, Yogyakarta: Kanisius, 2001.
Muslih, Mohamad, Sains Islam dalam Diskursus Filsafat Ilmu, dalam Jurnal Kalam: Jurnal Studi Agama dan Pemikiran Islam, Volume 8, Nomor 1, Juni 2014

Mustaqim, Abdul, Epistemologi Tafsir Kontemporer, Yogyakarta: LKiS Printing Cemerlang, 2012.

Qaththan, Manna', Pengantar Studi Ilmu Alquran, Terj. Aunur Rafiq El-Mazni, Jakarta: Pustaka Alkautsar, 2012.

Rahman, Fazlur, "Islam dan Modernitas" dalam Liberal Islam: A Sourcebook, terj. Bahrul Ulum, ed.Charles Kurzman, Jakarta: Paramadina, 2001.

Rohmana, Jajang A., "Rekonstruksi IImu-IImu Keislaman", dalam Kalam: Jurnal Studi Agama dan Pemikiran Islam, Volume 8, Nomor 1, Juni 2014

Sardar, Ziauddin, Kembali ke Masa Depan, Terj. R. Cecep Lukman Yasin dan Helmi Mustafa, Jakarta: Serambi Ilmu Semesta, 2005. , Reconstructing the Muslim Civilization, terj. AE. Priyono, Surabaya: Risalah Gusti, 2000.

Shihab, M. Quraish, Membumikan Alquran: Peran Wahyu dalam Kehidupan Masyarakat, Bandung: Mizan, 1994. , Menabur Pesan Ilahi: Alquran dan Dinamika Kehidupan Masyarakat, Jakarta: Lentera, 2006. , Tafsir Al-Mishbah: Pesan, Kesan, dan Keserasian Alquran, Jilid ke1-15, Jakarta: Lentera Hati, 2005

, Wawasan Alquran: Tafsir Maudhu'i atas Pelbagai Persoalan Umat, Bandung: Mizan, 1996.

Suriasumantri, Jujun S., Filsafat Ilmu Sebuah Pengantar Populer, Jakarta: Surya Mutia Grafika, 2005.

Suseno, Franz Magnis, Dalam epilog Charles Drawin, The Origin of Species, by Means of Natural Selection or the Preservatiom of Favoured Races in the Struggle for life, terj. TIM UNAS, Jakarta: Yayasan Obor Indonesia, 2003.

Tafsir, Ahmad, Epistemologi Untuk Ilmu Pendidikan Islam, Bandung: Fakultas Tarbiyah IAIN Sunan Gunung Djati Bandung, 1995.

, Filsafat Ilmu: Mengurai Ontologi, Epistemologi, dan Aksiologi Pengetahuan, Bandung: Rosdakarya, 2007. 